\title{
25. GEOCHEMISTRY OF FLUIDS AND FLOW REGIME IN THE DÉCOLLEMENT ZONE AT THE NORTHERN BARBADOS RIDGE ${ }^{1}$
}

\author{
M. Kastner, ${ }^{2}$ Y. Zheng, ${ }^{3}$ T. Laier, ${ }^{4}$ W. Jenkins, ${ }^{5}$ and T. Ito ${ }^{6}$
}

\begin{abstract}
The recent three-dimensional seismic reflection experiment at the décollement zone at the northern Barbados Ridge subduction zone shows variations in the amplitude and polarity of the décollement reflection; this suggests variations in fault-zone velocity and density, hence in porosity and pore-fluid pressure that drives the fluid and influences fluid/rock reactions. The two sites drilled across the décollement zone on Ocean Drilling Program Leg 156, Sites 948 and 949, representative of positive and negative polarity reflections, are located 4 and $2 \mathrm{~km}$, respectively, west of the deformation front.

Geochemical and temperature depth profiles indicate a mainly lateral, focused along faults, flow (eastward) of a warm fluid significantly fresher than seawater at both the positive and negative polarity sites. The fluid with the lower than seawater chloride concentration observed at the top of the décollement zone at Site 948 ( 18\% dilution) and enriched in I, Ca, Sr, Ba, Mn, $\mathrm{Mo}, \mathrm{Zn}$, and Co, is advecting from a source region that is situated deeper than the drilled depths and more arcward. A slight increase in methane concentration relative to background level indicates a source region rich in organic matter. The fluid originates from transformation reactions, including dehydration, of terrigenous clay minerals as indicated by the radiogenic strontium and helium-isotope ratios of the source fluid. In situ volcanic ash alteration reactions considerably overprint the geochemical signatures of the end-member low-Cl fluid.

The chemistry and isotopic composition of the carbonate vein minerals indicate that they have precipitated from a geochemically distinct fluid from the in situ pore fluids. Injection of fluid from a deeper and hotter source caused hydrofracturing and mineralization. The multiple generations of vein carbonates imply episodic fluid-flow events, and the strong in situ diagenetic overprinting of the pore fluids suggests that a major fluid-flow episode has not occurred recently. The methane peak, however, signifies active fluid advection.
\end{abstract}

The pore fluids in the accreted and underthrust sediments are geochemically distinct, indicating little vertical advection.

\section{INTRODUCTION AND GENERAL BACKGROUND}

Recent advances in subduction zones research have reinforced the notion that fluids play a critical role in virtually all geologic processes in this environment (e.g., von Huene, 1984; Moore et al., 1990, and references therein). Tectonic forces in subduction zones cause migration and expulsion of pore fluids by thickening the sedimentary load and reducing porosity (e.g., Bray and Karig, 1985; Shi and Wang, 1988; Bangs et al., 1990; Moore and Vrolijk, 1992) and generate fluids by dehydrating, transforming, and dissolving hydrous minerals. These fluids may induce high pore-fluid pressures and hydrofracturing, trigger earthquakes, and are also involved in arc volcanism. The associated fluid/rock reactions influence the physical, chemical, and thermal properties of the accreted and underthrust sediments. Furthermore, the expelled fluids contain key geochemical components that they carry into the ocean, including environmentally important ones (i.e., $\mathrm{CO}_{2}, \mathrm{CH}_{4}$, and others; e.g., Peacock, 1990; Gieskes et al., 1990a; Kastner et al., 1991, and references therein) that may be a significant factor in seawater chemistry (e.g., Han and Suess, 1989; Kastner et al., 1991; Martin et al., 1991).

Previous field studies as well as geochemical and thermal modeling of the nature of fluid flow have emphasized the importance of focused flow along the décollement and other major faults, through

${ }^{1}$ Shipley, T.H., Ogawa, Y., Blum, P., and Bahr, J.M. (Eds.), 1997. Proc. ODP, Sci. Results. 156: College Station. TX (Ocean Drilling Program)

${ }^{2}$ Scripps Institution of Oceanography, University of California, San Diego, La Jolla, CA 92093-0212, U.S.A. mkastner@ucsd.edu

${ }^{3}$ Lamont-Doherty Earth Observatory of Columbia University, Palisades, NY 10964, U.S.A.

${ }^{4}$ Geological Survey of Denmark, Thoravej 8, DK-2400, Copenhagen, Denmark

${ }^{5}$ Woods Hole Oceanographic Institution, Woods Hole, MA 02543, U.S.A.

${ }^{6}$ Faculty of Education, Ibaraki University, Mito, Ibaraki 310, Japan. vents or mud volcanoes, and along sand horizons (e.g., Kulm et al., 1986; Henry et al., 1989, 1992; Fisher and Hounslow, 1990; Foucher et al., 1990; Moore et al., 1990). The orders of magnitude discrepancy between calculated maximum possible rates of fluid discharge and the few, short-term measurements of rates of focused fluid discharge that are greater than the fluid input rate (i.e., Carson, 1977; Carson et al., 1990; Foucher et al., 1990; Le Pichon et al., 1990; Linke et al., 1994), most likely implies that the flow is episodic and may be related to earthquake activity. Heat-flow modeling (Fisher and Hounslow, 1990), the recent study of the geochemistry of vein minerals at the northern Barbados Ridge décollement (Labaume et al., Chapter 5, this volume), and modeling of the low-Cl fluid at that horizon (Bekins et al., 1995) support this conclusion. In addition to focused flow along tectonic or sedimentologic conduits, expulsion of fluids also occurs by dispersive flow through the sediments. Determining the relative importance of the two modes of fluid flow and the associated mass fluxes is an ultimate goal for understanding the fundamental hydrogeological and geochemical processes in subduction zones and their global environmental significance.

The observation of focused fluid flow from an arcward source mostly along faults, with the décollement as the main conduit at the northern Barbados Ridge, made on Ocean Drilling Program (ODP) Leg 110 (e.g., Moore et al., 1988; Gieskes et al., 1990a, 1990b; Fisher and Hounslow, 1990; Vrolijk et al., 1990) was followed by a three dimensional (3-D) seismic reflection experiment Shipley et al. (1994) conducted, with its main objective to better image and map the décollement off Barbados. The 3-D data show variations in the amplitude and polarity of the décollement reflection, suggesting variations in fault-zone velocity and density, and hence in porosity and porefluid pressure and flow at this major thrust boundary (Shipley et al., 1994, 1995; Moore et al., 1995; Bangs et al., 1996).

One of the main objectives of ODP Leg 156 thus was to understand the relations between the spatial variations of the in situ physi- 
cal properties, especially pore-fluid pressure and porosity, and the seismic-reflection signatures of the décollement. The two sites drilled across the décollement zone on Leg 156, Sites 948 and 949, are representative of positive and negative polarity regions, and are located approximately 4 and $2 \mathrm{~km}$, respectively, west of the thrust front (Fig. 1). Site 948 is located next to Site 671, which was drilled on Leg 110; Site 949 was not drilled previously. The décollement zone was penetrated at both sites.

\section{SITES DRILLED}

The important characteristics that influence the hydrogeochemistry in the vicinity of the décollement zone at the northern Barbados Ridge subduction zone are summarized below. Further details about these sites are provided mostly in Shipley, Ogawa, Blum, et al. (1995), Moore et al. (1995), Underwood and Deng (Chapter 1, this volume), and Meyer and Fisher (Chapter 27, this volume).

Site 948 is situated $\sim 4 \mathrm{~km}$ arcward of the deformation front (Fig. 1) and within about $200 \mathrm{~m}$ of Hole 671B of Leg 110 (Moore et al., 1988). Average core recovery was high, $>90 \%$, and the sediments are clay rich. At the décollement zone, the clay content ranges between $70 \%$ and $90 \%$ (Meyer and Fisher, Chapter 27, this volume), and its mineralogy changes considerably, from $60 \%$ to $10 \%$ smectite, with a corresponding increase in illite and kaolinite contents (Underwood and Deng, Chapter 1, this volume). Organic C content is low, mostly $<0.05 \%$, but in specific thin layers below the décollement it rises to $>1 \%$. The accreted section is $\sim 500 \mathrm{~m}$ thick and composed of Quaternary to lower Miocene clay-rich sediments, and the underthrust section is also $\sim 500 \mathrm{~m}$ thick and consists of lower Miocene to Oligocene mudstones. Except for two anomalously high-porosity thin layers at the décollement (Moore et al., 1995), between 400 mbsf and the lithologic break in the décollement zone, porosities vary between $50 \%$ and $60 \%$; below the lithologic boundary porosity varies mostly between $40 \%$ and $55 \%$. The little cementation found suggests that porosity reduction is principally due to consolidation by loading.

The décollement is characterized by a normal polarity reflection. The décollement zone, which is $\sim 35 \mathrm{~m}$ thick, is located at $\sim 494-530$ $\mathrm{m}$ below seafloor (mbsf) and is characterized by scaly fabric and a major lithologic change that occurs at $\sim 514$ mbsf. The lithologic break is reflected in pronounced changes in physical properties across the décollement zone, as seen in the various logs. The porefluid pressure rises from hydrostatic in the uppermost $100 \mathrm{~m}$ of the accreted section to $>90 \%$ lithostatic below thrusts in the prism and at the décollement (Moore et al., 1995). Veins filled mostly with carbonate minerals occur only in the accreted section, above the décollement zone. The geothermal gradient is very high, at $92^{\circ}$ to $97^{\circ} \mathrm{C} / \mathrm{km}$ in the first $100 \mathrm{~m}$, and is $66^{\circ} \mathrm{C} / \mathrm{km}$ deeper in the hole. At the top of the décollement zone, an important fluid conduit was identified geochemically. Other less intense or "dead" conduits, situated along faults, also exist. A CORK was installed to provide temperature and pressure records for $>2 \mathrm{yr}$.

Site 949 is situated $\sim 2 \mathrm{~km}$ arcward of the deformation front (Fig. 1 ). Core recovery was very poor, but on the basis of the limited recovery it seems that the sedimentology and vein distribution at this site are similar to that at Site 948. At this site, however, average porosities are higher by $\sim 5 \%$ both above and below the décollement zone. The accreted sediment section is thinner, and the décollement is shallower by $\sim 100 \mathrm{~m}$; the décollement zone is at about $400-437$ mbsf and characterized by a negative polarity reflection of intermediate amplitude. An important thrust fault that acts as a fluid conduit occurs at 292-302 mbsf. The deformation is less intense than that at Site 948 , and the geothermal gradient is $\sim 80^{\circ} \mathrm{C} / \mathrm{km}$ and linear. Despite the low recovery, on the basis of $\mathrm{Cl}$ concentrations, three minor fluid conduits were identified, of which the deepest at $425 \mathrm{mbsf}$ is associated with the décollement zone.

A CORK was installed, and in addition to temperature and pressure measurements, a continuous fluid osmo-sampler will collect fluids for $\sim 2.5 \mathrm{yr}$. The sampler is described in Kastner (1996) and Jannasch and Kastner (1995).

\section{MAIN OBJECTIVES}

The main geochemical objectives of ODP Leg 156 were to

1. document the presence of fluid flow and map the spatial variability of the flow;

2. constrain the dominant fluid/rock reactions that control the geochemistry of the pore fluids;

3. establish the extent of geochemical "communication" across the décollement zone between the underthrust and accreted sediment sections;

4. determine the relative importance of focused and dispersive fluid flow, and thus establish the role of faults in fluid transport;

5. determine if the fluid conduits are connected;

6. identify the source(s) of the fluid(s), especially of the fluid associated with the décollement zone;

7. find evidence for the nature of fluid flow, if episodic or constant;

8. evaluate the relations between the polarity and amplitude of the décollement reflection waveform and the nature and intensity of fluid flow; and

9. deploy a sampler for long-term continuous monitoring of the chemistry of the fluid at the décollement.

The techniques used for obtaining these objectives included chemical and isotopic analyses of pore fluids, terrigenous sediments, and authigenic minerals (i.e., vein-filling minerals) as well as petro-
Figure 1. Schematic section of the Leg 156 drilling sites (from Shipley, Ogawa, Blum, et al., 1995). NBR $=$ northern Barbados Ridge, and LWD = loggingwhile-drilling.

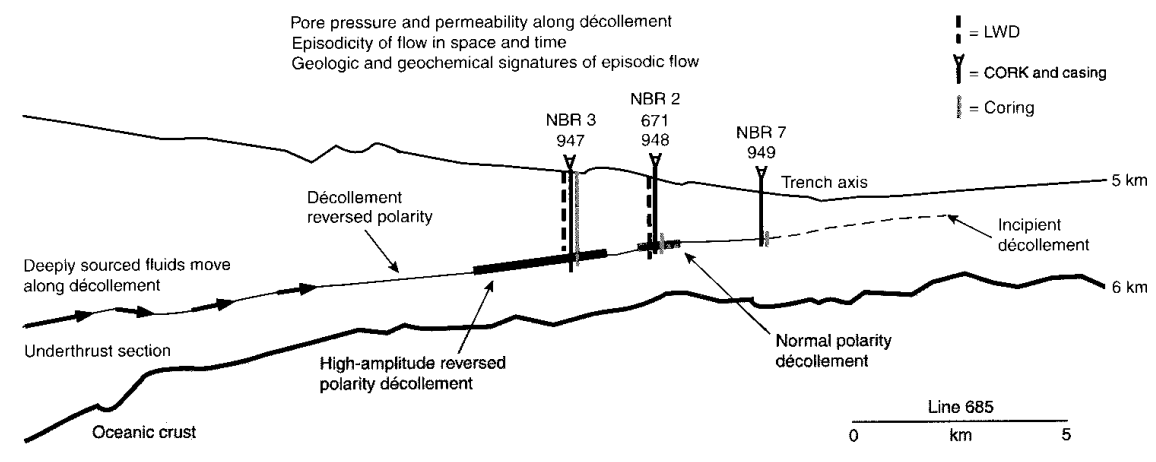

Pore pressure and permeability along décollement

NBR 2

$i=L W D$

$Y=$ COFK and casing

I = Coring 
graphic, X-ray, and SEM observations of the solid phases. Samples used consisted of pore fluids separated from deep-sea sediments by squeezing and squeezed and intact sediment samples. In addition to the shipboard chemical analyses described in Shipley, Ogawa, Blum, et al. (1995), the shore-based chemical and isotopic results are documented in Zheng and Kastner (Chapter 12, this volume), Kastner and Zheng (Chapter 29, this volume), and Labaume et al. (Chapter 5, this volume).

\section{RESULTS AND DISCUSSION Main Results from ODP Leg 110}

The main geochemical results obtained on Leg 110 as described in Moore et al. (1988) Gieskes et al. (1990a, 1990b) and Vrolijk et al. (1990) show that a low-Cl fluid originates arcward, which explains the observed overall decrease in $\mathrm{Cl}$ concentrations away from the deformation front. At Site 671 (which is adjacent to Site 948), the maximum $\mathrm{Cl}$ dilution of about $10 \%$, located within the décollement zone, is accompanied by a small methane spike and shows a slight increase in the $\delta^{18} \mathrm{O}$ value. In addition, the nonsteady-state $\mathrm{Cl}$ concentration depth profiles suggest that focused flow occurs along faults, the décollement, and apparently through an Oligocene to Eocene sandstone in the underthrust section; the sandstone was not reached during Leg 156. The major element chemistry, especially the $\mathrm{Ca}$ and $\mathrm{Mg}$ concentration depth profiles and the few preliminary Sr-isotope values, suggests that the important diagenetic reactions are volcanic ash alteration and exchange with formation water in the underlying oceanic basement. The concentration profiles of the major constituents observed do not support pervasive fluid advection. Membrane filtration or clay minerals dehydration were proposed as possible processes for the origin of the low-Cl fluid. The latter reaction is favored because the observed slight increase in the $\delta^{18} \mathrm{O}$ value at the décollement zone at Site 671 (Vrolijk et al., 1990) is difficult to explain by membrane filtration.

\section{Main Results from ODP Leg 156}

The shipboard geochemical methods used and data obtained during Leg 156 are summarized in Shipley, Ogawa, Blum, et al. (1995); the shore-based methods and data are provided in Zheng and Kastner (Chapter 12, this volume) and Kastner and Zheng (Chapter 29, this volume).

The nonsteady-state concentration depth profiles of the major constituents with concentration maxima and minima centered on faults at both sites (Figs. 2 through 4) indicate that focused fluid flow is the prevailing mode of fluid migration. At Site 948, the good recovery and high-resolution pore-fluid sampling in the vicinity of the décollement precisely locate the main fluid conduit at the top of the décollement zone, instead of within it, and indicate that the $\mathrm{Cl}$ (and other components) concentration in the fluids is almost twice as dilute ( $18 \%$ seawater dilution) as was observed on Leg 110 at Site 671 . The extent of dilution at Site 948 is equal to the maximum Cl dilution observed during Leg 110 at the western-most drill site, Site 674 , located about $13 \mathrm{~km}$ arcward from Site 948 . The $\mathrm{Ca}, \mathrm{Mg}, \mathrm{Li}$, and $\mathrm{Rb}$ concentration depth profiles and $\mathrm{Na} / \mathrm{Cl}$ values (Figs. 2C, 2D) reaffirm the importance of in situ volcanic ash alteration reactions, especially in the accreted section, and emphasize that the exchange with oceanic basement formation fluids is most important in the underthrust section (for detailed discussion see Martin et al., 1991; Kastner et al., 1995). Especially on the basis of Li data, the basement reactions occur at moderate temperatures of $\leq 100^{\circ}-120^{\circ} \mathrm{C}$. The above mentioned chemical data also rule out membrane filtration as a possible process for the generation of the advecting low-Cl fluid that strongly influences the geochemistry of the pore fluids, particularly in the accreted sediments. Detrital clay transformation reactions
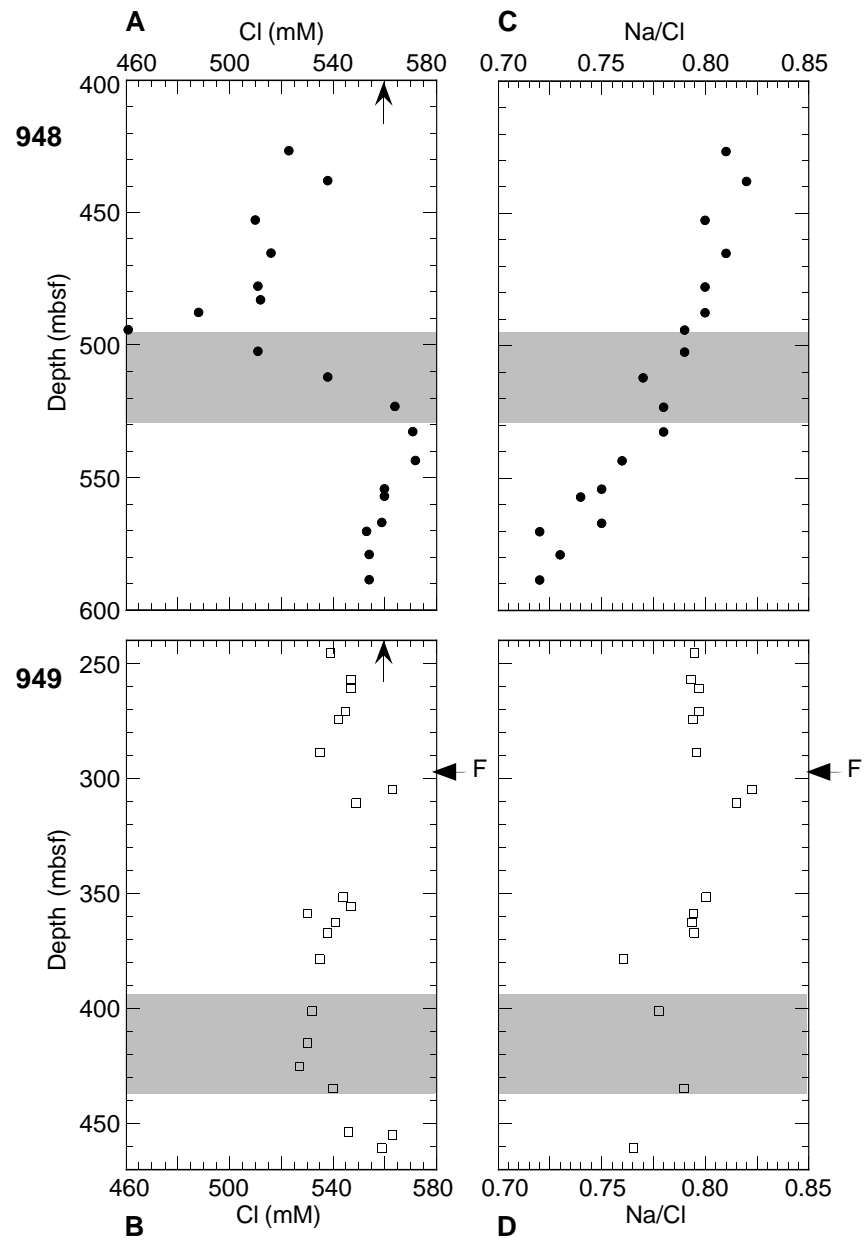

Figure 2. Depth profiles of $\mathrm{Cl}$ concentration in pore fluids from (A) Site 948 and (B) Site 949, and Na/Cl values from (C) Site 948 and (D) Site 949. The stippled areas delineate the décollement zone. The vertical arrows indicate modern seawater composition, and the horizontal arrows marked by " $F$ " indicate a fault zone (based on data in Shipley, Ogawa, Blum, et al., 1995).

accompanied by dehydration are clearly responsible for the generation of the advecting low-Cl fluid, as discussed below.

The high sulfate concentration in the pore fluids at Site 948 excludes generation of methane in substantial amounts; therefore, the peak in methane concentration at the top of the décollement is caused by advection of fluid from an organic source region. The low-Cl fluid is also enriched in $\mathrm{I}, \mathrm{Ca}, \mathrm{Sr}, \mathrm{Ba}, \mathrm{Mn}, \mathrm{Mo}, \mathrm{Zn}$, and $\mathrm{Co}$ (Kastner and Zheng, Chapter 29, this volume; Zheng and Kastner, Chapter 12, this volume). Specifically, the I, Mo, Zn, and Co enrichments support an organic-rich sediment at the source. The $\mathrm{Sr}$ - and He-isotope ratios indicate a continental (detrital) source.

The pore-fluid chemistries of the accreted and underthrust sediment sections are noticeably different. In the accreted section pore fluid, the concentrations of $\mathrm{Cl}, \mathrm{Br}, \mathrm{Li}, \mathrm{K}, \mathrm{Rb}, \mathrm{Ca}, \mathrm{Mg}, \mathrm{Sr}, \mathrm{Mn}, \mathrm{Co}$, ammonium, and alkalinity are lower; Mo concentration and $\mathrm{K} / \mathrm{Rb}$ values are higher; $\mathrm{Sr} / \mathrm{Cl}, \mathrm{Na} / \mathrm{Cl}$, and $\Delta \mathrm{Ca} / \Delta \mathrm{Mg}$ values are lower $(\Delta$ designates deviations from modern seawater concentration); ${ }^{87} \mathrm{Sr} /{ }^{86} \mathrm{Sr}$ values are less radiogenic; and $\delta^{18} \mathrm{O}$ values are less negative (the detailed data are in Shipley, Ogawa, Blum, et al., 1995; Kastner and Zheng, Chapter 29, this volume; Zheng and Kastner, Chapter 12, this volume). Although minor chemical differences exist above and below the incipient décollement already at the "reference" Site 672 (Gieskes et al., 1990a, 1990b), the majority of the differences must 

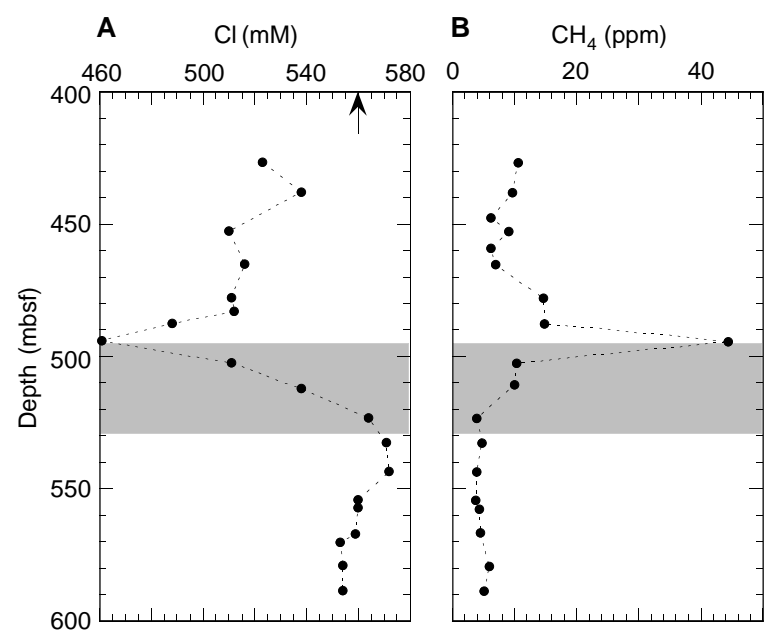

Figure 3. Depth profiles of (A) $\mathrm{Cl}$, and (B) $\mathrm{CH}_{4}$ concentrations in pore fluids of Site 948 (based on data in Shipley, Ogawa, Blum, et al., 1995). Arrow symbol as in Figure 2.

have developed since the hemipelagic section has crossed the deformation front. In situ fluid/rock reactions with the different lithologies above and below the décollement zone (Shipley, Ogawa, Blum, et al., 1995; Underwood and Deng, Chapter 1, this volume) under different pore-fluid pressure regimes must have produced some of the observed geochemical differences. The more pervasive lateral fluid flow in the accreted section, hence, more extensive mixing between the exotic fluid advecting from deeper and farther arcward in the subduction zone and the in situ pore fluid, is also responsible for these chemically distinctive fluid regimes. The lack of pervasive vertical dispersive advection is thus clear; vertical advection at $>1 \mathrm{~mm} / \mathrm{yr}$ would have erased some and smoothed out the other geochemical differences described. Either the very high pore-fluid pressure, almost lithostatic, at the décollement zone (Moore et al., 1995) or the permeability anisotropy in this clay-rich subduction zone may be responsible for the little geochemical "communication" between the accreted and underthrust sediments at this region of the northern Barbados subduction zone.

\section{Chemical and Isotopic Evidence for Fluid Flow and Sources}

Site 948, where a continuous high-resolution pore-fluid data set was obtained, is emphasized over Site 949 in the following discussion.

\section{Chloride and Methane}

The most distinctive characteristics of the concentration depth profiles of dissolved chloride are (1) the sharp Cl minimum (461 mM, $\sim 18 \%$ seawater $\mathrm{Cl}$ dilution) at Site 948 , situated at the top of the décollement zone (Figs. 2A, 3A; Shipley, Ogawa, Blum, et al., 1995), which is a dilution almost twice that observed at adjacent Site 671 (within $200 \mathrm{~m}$ of this site); and (2) the observation that at both sites, all the pore fluids in the accreted sediments are fresher than seawater, whereas in the underthrust section they are not fresher (Figs. 2A, 2B), suggesting that whatever the origin of the low-Cl fluid is, its influence on the geochemistry of the accreted section is more pronounced, and that the vertical communication between the fluids in the accreted and underthrust sections is minimal. The width and shape of the main $\mathrm{Cl}$ anomaly peak at Site 948 suggest that injection of the low$\mathrm{Cl}$ fluid occurred a few thousand to $20,000 \mathrm{yr}$ ago. The asymmetry of this $\mathrm{Cl}$ anomaly peak is most likely caused by the change in lithology and in the physical properties, including formation factors (inpermeabilities and sediment diffusion coefficients), within the décollement
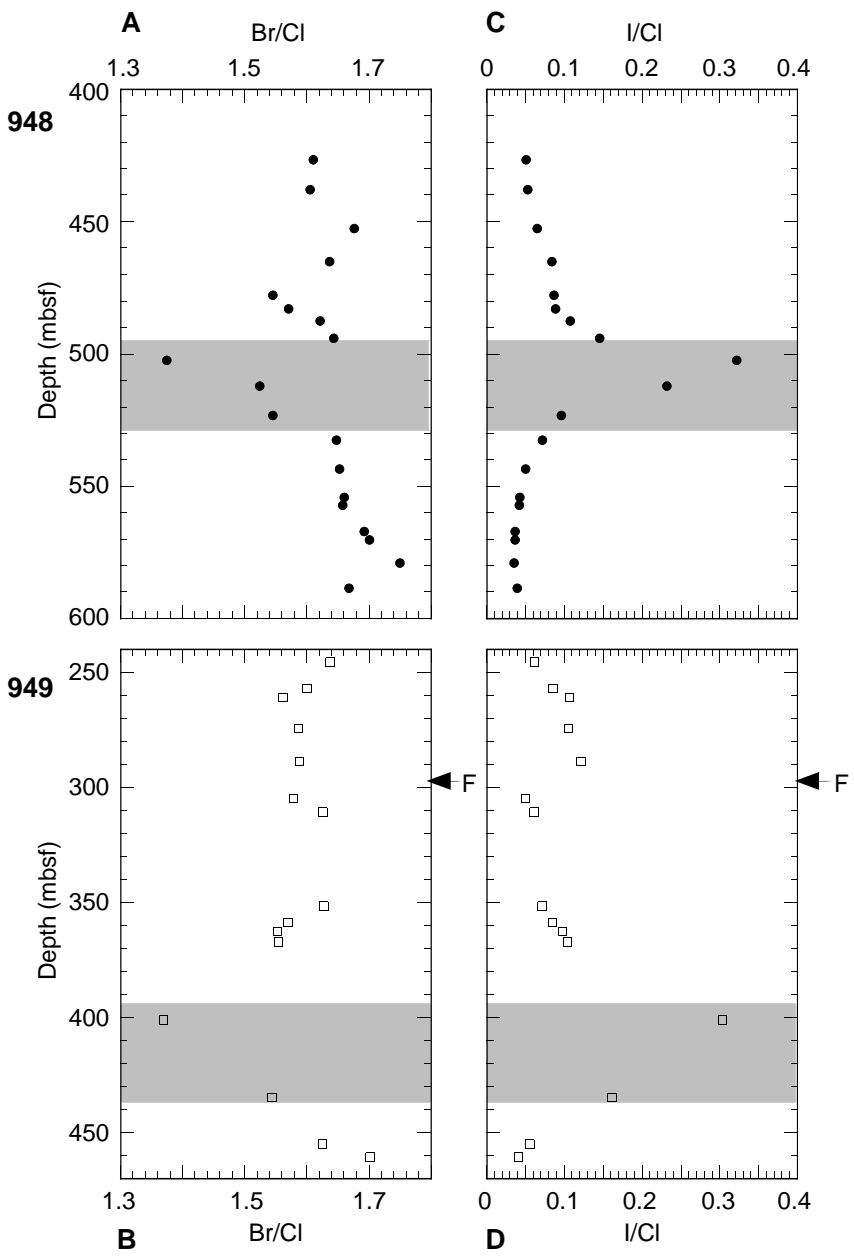

Figure 4. Depth profiles of $\mathrm{Br} / \mathrm{Cl}$ values in pore fluids from (A) Site 948 and (B) Site 949, and I/Cl values from (C) Site 948 and (D) Site 949 (based on data in Kastner and Zheng, Chapter 29, this volume). Arrows as in Figure 2.

zone (Shipley, Ogawa, Blum, et al., 1995). The minor $\mathrm{Cl}$ minimum at Site 948 , at $\sim 453$ mbsf, may suggest a less intense fluid injection episode or may be a relict of an old event. The former option is preferred because of the presence of the minor methane maximum (Fig. 3B).

No known in situ reaction could have generated the low-Cl fluid observed at the top of the décollement, where the porosity is $\sim 55 \%$ and the temperature is $\sim 40^{\circ} \mathrm{C}$ (Shipley, Ogawa, Blum, et al., 1995). The most likely reaction that could generate the dilution is the smectite to illite transformation accompanied by dehydration, which begins at $\sim 60^{\circ}$ and proceeds more rapidly at $90^{\circ} \mathrm{C}$ (e.g., Perry and Hower, 1970; Freed and Peacor, 1989a, 1989b, and references therein). Within this temperature window, to dilute in situ the pore-fluid $\mathrm{Cl}$ by almost $20 \%$ at $55 \%$ porosity, a sediment containing almost $100 \%$ smectite would have to be fully transformed to illite. The detailed clay mineralogy analyses by Underwood and Deng (Chapter 1, this volume), however, do not support such a scenario; they observed very little clay diagenesis within the clay-rich sections drilled at both sites. Therefore, the source of the low- $\mathrm{Cl}$ fluid must be elsewhere, located deeper and arcward.

At Site 949 in the accreted section, pore-fluid $\mathrm{Cl}$ concentrations are also lower than in seawater; however, the $\mathrm{Cl}$ dilution is of lesser intensity, most probably because this site is closer to the deformation front and the fluid transport is from west to east.

In summary, the sharp $\mathrm{Cl}$ minimum at the top of the décollement at Site 948 and the lesser minima at both sites (Figs. 2A, 2B), together with the pronounced differences in $\mathrm{Cl}$ concentrations in the accreted 
and underthrust sediment sections, highlights the dominance of laterally focused fluid transport at the northern Barbados subduction zone.

Another important characteristic of the hydrogeochemical regime at this region of the Barbados subduction zone is the distinct methane concentration maximum at the top of the décollement of Site 948 (Fig. 3B). Its occurrence at the exact depth of the sharp $\mathrm{Cl}$ minimum (Fig. 3A), is not coincidental, especially in these sulfate-rich pore fluids $(\sim 15 \mathrm{mM}$ sulfate). Because sulfate-reducing bacteria rapidly oxidize methane, this methane peak could be obtained only by mixing of fluids because of fluid flow. Mixing of a methane-containing fluid with the in situ sulfate-rich pore fluid must have occurred in the recent past. The large range in the $\delta^{13} \mathrm{C}$ methane values of $-22 \%$ o to $-36 \%$ (Laier, 1996), is most likely caused by the coupled sulfate reduction and anaerobic methane consumption reaction (e.g., Whiticar et al., 1995) and less likely has a thermogenic origin. The shift in the methane $\delta^{13} \mathrm{C}$ values by methanotrophy makes it difficult to determine its origin solely on the basis of the isotopic value. The high proportion of methane relative to higher hydrocarbons $\left(\mathrm{C}_{2}-\mathrm{C}_{5}\right)$ points to either a bacterial source or to a highly mature source rock $\left(\mathrm{C}_{2}\right.$ hydrocarbons having been cracked to methane at $>200^{\circ} \mathrm{C}$ ), which must be situated deeper in the sediment section, having higher organic matter content than the $<0.1 \%$ total organic carbon (TOC) observed in most of the sediments drilled. The sulfate-concentration profiles decrease more rapidly with depth, and ammonium concentrations increase in the Paleocene sediments close to the base of the sections drilled (Shipley, Ogawa, Blum, et al., 1995), suggesting that at greater depth and arcward, organic-matter-rich sediments exist and most probably are the source for the methane. The belief that the source region of the low-Cl fluid has sediments enriched in organic matter is also supported by the observations that the freshest fluid at the top of the décollement zone, Site 948, has elevated concentrations of Mo, Zn, Co, and I, but not $\mathrm{Br}$ (for example, see Fig. 4), as discussed in Zheng and Kastner (Chapter 12, this volume) and Kastner and Zheng (Chapter 29 , this volume).

\section{Strontium Concentrations and Strontium- and Oxygen-Isotope Ratios}

Sr concentrations provide information on the composition of the solids that react with the fluid. Reactions of fluid with volcanic material and most detrital silicates, other than quartz, would raise its $\mathrm{Sr}$ concentrations. The Sr concentrations, although lower at the décollement at both sites (Kastner and Zheng, Chapter 29, this volume), are considerably less diluted than $\mathrm{Cl}$. In the accreted sediment section, a $100 \mathrm{mM}$ depletion in $\mathrm{Cl}(\sim 18 \%)$ corresponds to a $30 \mu \mathrm{M}(\sim 13 \%)$ depletion in Sr, as shown in the almost vertical line in Figure 5. Thus, the low- $\mathrm{Cl}$ fluid is enriched in $\mathrm{Sr}$ relative to the fluid with the high$\mathrm{Cl}$ concentration. Figure 5 also emphasizes the distinctive chemistry of the underthrust sediment pore fluids, as represented by the almost horizontal line.

Most importantly, however, because $\mathrm{Sr}$ isotopes do not fractionate during geochemical processes, they clearly indicate the sources and sinks of the materials involved in the processes. The pore-fluid Sr-isotope data of both sites are significantly less radiogenic (lower ${ }^{87} \mathrm{Sr} /{ }^{86} \mathrm{Sr}$ values) than modern or contemporaneous seawater $\mathrm{Sr}$ isotope values (e.g., Burke et al., 1982; Kastner and Zheng, Chapter 29 , this volume). Mostly in situ volcanic glass alteration with some contribution from basement alteration are responsible for this shift, represented by Line A in Figure 6; it shifts the pore waters toward less radiogenic $\mathrm{Sr}$ isotopes and elevated $\mathrm{Sr}$ concentrations. Line B represents the décollement zone and shows mixing between the in situ geochemically highly altered pore fluids and a significantly more radiogenic fluid that is also rich in $\mathrm{Sr}$. To test if reactions with the detrital fraction of the sediments composed primarily of terrigenous clay minerals could be the source of the radiogenic $\mathrm{Sr}$, carbonate-free bulk sediments were analyzed for $\mathrm{Sr}$ concentration and isotopic com-

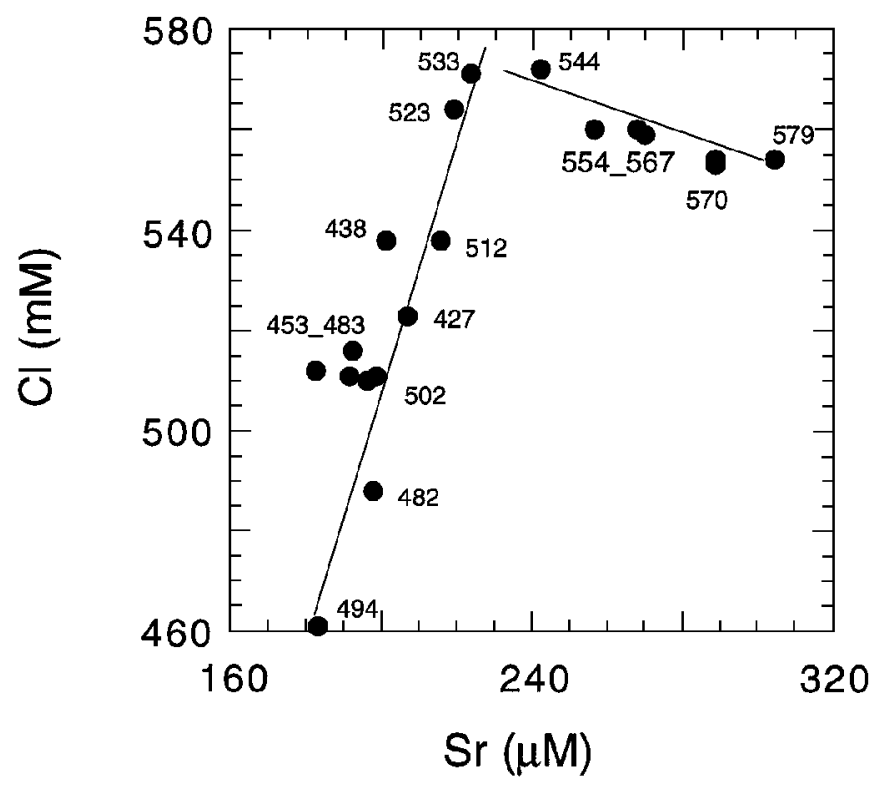

Figure 5. Mixing relations between $\mathrm{Cl}$ and $\mathrm{Sr}$ concentrations of pore fluids from Hole 948C. The numbers next to the data points mark their depths in mbsf. Straight lines indicate mixing between two end members. The nearly vertical line represents mixing relations in the accreted section and décollement zone, and the nearly horizontal line represents the underthrust section (based on data in Shipley, Ogawa, Blum, et al. [1995] and in Kastner and Zheng [Chapter 29, this volume]).

position. The data summarized in Table 1 clearly support the conclusions that the generation of the low- $\mathrm{Cl}$ fluid and the dehydration and transformation reactions involving the terrigenous clay minerals are intimately related; the advecting low-Cl fluid is enriched in $\mathrm{Sr}$ from a continental radiogenic source. The He-isotopic ratios discussed in the following section also point toward a continental source. Line $\mathrm{C}$ in Figure 6, which represents the pore fluids in the underthrust sections of Sites 948 and 949, shows that below the décollement zone, Sr-isotope ratios remain constant, whereas $\mathrm{Sr}$ concentrations increase with depth.

The existence of veins indicates focused fluid flow, and vein minerals are excellent recorders of hydrogeochemistry (e.g., Sibson, 1981; Vrolijk and Sheppard 1991, and references therein). Interestingly, at Sites 948 and 949 carbonate and other veins occur only in and above the décollement zone and do not occur below it (Labaume et al., Chapter 5, this volume). Most of the veins are spatially associated with fault zones. Labaume et al. (Chapter 5, this volume) identified and characterized four vein types, all consisting of mostly Mn-rich carbonates, rhodochrosite, and Mg-kutnohorite. Vein microstructures indicate that their formation is related to episodes of dilatancy, during which high pore pressures cause hydraulic fracturing. The best-developed veins are those of Type 4 described in Labaume et al. (Chapter 5 , this volume). They consist of several generations of carbonates that were analyzed for Sr-, C-, and O-isotope ratios. Figure 7, representing figure 14 in Labaume et al. (Chapter 5, this volume), indicates that the carbonates have precipitated from a fluid distinct from the presentday in situ fluid, as plotted within the field described by the dashed line. The vector connecting the in situ pore fluids with Generations 1 and 3 (G1 and G3) Type 4 vein carbonates shows that the carbonate of each vein generation has a different chemical and isotopic composition and that the first generation is isotopically closer to the in situ diagenetically altered pore fluids than the third generation. Also, the trend of increasing $\mathrm{Sr}$ concentrations and ${ }^{87} \mathrm{Sr} /{ }^{86} \mathrm{Sr}$ values from Generations 1 to 3 is evident. Because the $\mathrm{Sr}$ distribution coefficient in carbonate is also temperature dependent, the different Sr concentra- 

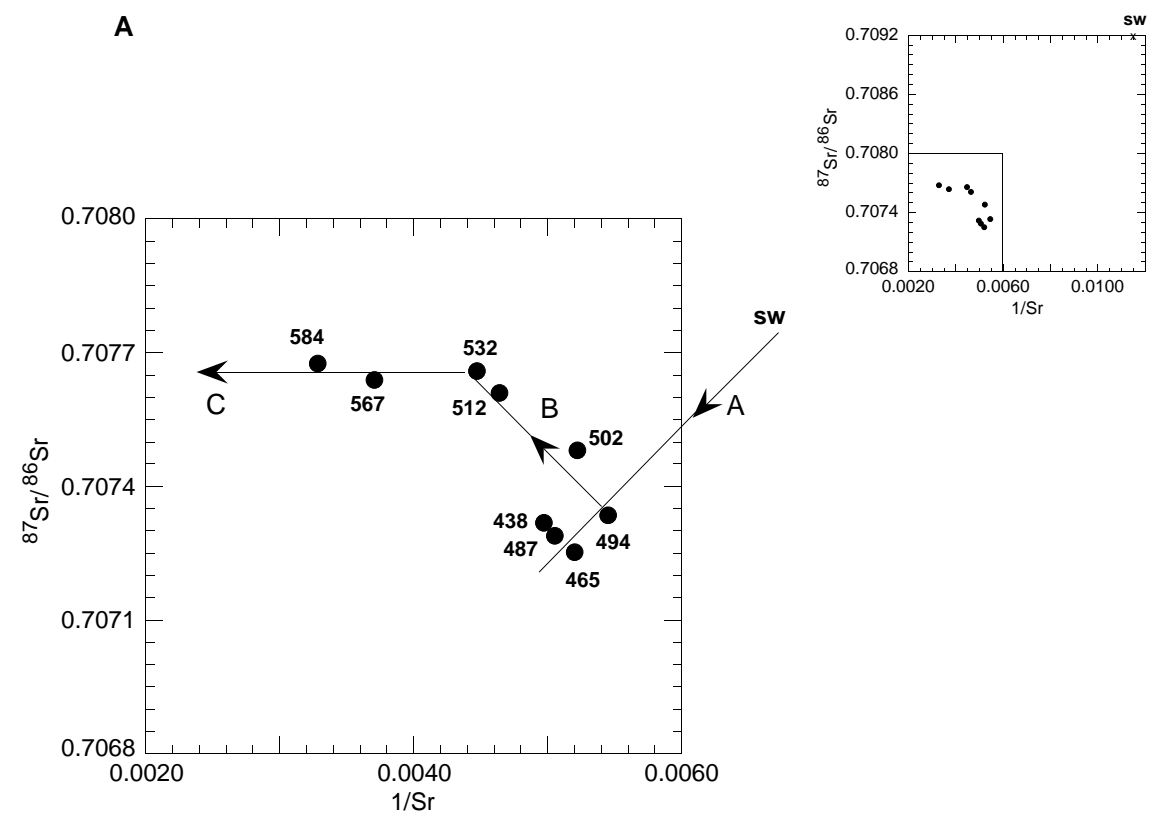

Figure 6. Mixing relations between ${ }^{87} \mathrm{Sr} /{ }^{86} \mathrm{Sr}$ and $1 / \mathrm{Sr}$ concentrations (in $\mu \mathrm{M}$ ) of pore waters from (A) Hole 948C and (B) Site 949. Seawater is designated "SW". The numbers next to the data points mark their depths in mbsf. The solid lines with arrows indicate the directions in which the pore-fluid $\mathrm{Sr}$ concentrations and isotopic compositions change within the marked depth intervals. Straight lines indicate mixing between two end members. Line A represents the accreted section, Line B represents the décollement zone, and Line $\mathrm{C}$ represents the underthrust section. The reduced figure in the upper right shows the spatial relation between the pore-fluid data field enlarged in the main figure and seawater on this mixing diagram (based on data in Kastner and Zheng [Chapter 29, this volume]). ${ }^{87} \mathrm{Sr} /{ }^{86} \mathrm{Sr}$ value of modern seawater is 0.70917 (Table 1 ).

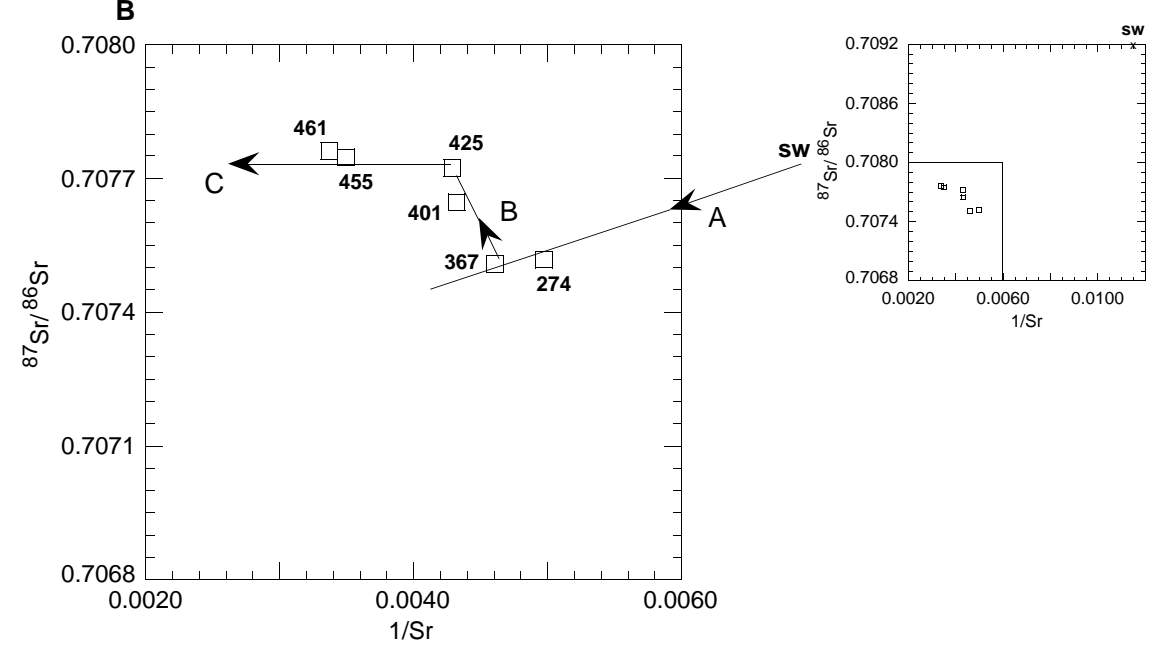

tions of the vein generations could originate from changes in the $\mathrm{Sr}$ concentration of the fluids and/or from variable temperature. The oxygen and carbon isotopic compositions of these vein-filling generations are also different, vary systematically with the Sr isotopes, and show a decreasing trend from Generations 1 to 3 (Kastner and Zheng, Chapter 29, this volume; Labaume et al., Chapter 5, this volume). Within the décollement zone of Site 948 , the $\delta^{18} \mathrm{O}$ values of the pore fluids are about $-2.1 \%$ o SMOW (standard mean ocean water). At the in situ temperature of $\sim 40^{\circ} \mathrm{C}$, an inorganically precipitated calcium carbonate would have a $\delta^{18} \mathrm{O}$ value of $-7.2 \%$ PDB (Peedee belemnite; O’Neil et al., 1969; McCorkle et al., 1990). The $\delta^{18} \mathrm{O}$ values of Generations 1 and 3 vein carbonates, however, are considerably higher, 5.3\%o and 3.1\%o PDB, respectively. Assuming these Mn- and/or $\mathrm{Mg}$-rich vein carbonates do not have extremely different fractionation factors than pure calcite, the positive $\delta^{18} \mathrm{O}$ values of the vein carbonates indicate that the $\delta^{18} \mathrm{O}$ values of the pore fluids from which they precipitated were approximately $8 \%$ o to $10 \%$ SMOW at the in situ temperature of $40^{\circ} \mathrm{C}$. At higher in situ temperatures, the pore-fluid $\delta^{18} \mathrm{O}$ values would have been even more positive. Thus, the oxygen isotopic data of these vein carbonates are consistent with the suggestion that clay mineral dehydration and transformation reactions at elevated temperatures of at least $150^{\circ}-200^{\circ} \mathrm{C}$ are responsible for the freshening of the pore fluids. After the precipitation of the vein-filling carbonates, in situ alteration of mostly volcanic ash has shifted the $\delta^{18} \mathrm{O}$ value of the pore fluid to $-2.1 \%$ SMOW.

Thus, the chemistry and isotopic compositions of Type 4 vein carbonates indicate that these vein-filling carbonates precipitated from a non-in situ fluid that was injected from a deeper and hotter arcward source, causing hydrofracturing and mineralization. Generation 3 represents the latest, most pristine subpulse of fluid injection of this episodic fluid-flow event along the Barbados décollement, which must have influenced the regional thermal regime. Although the present-day pore fluid is highly overprinted by in situ diagenetic reactions with volcanic glass and/or basement alteration, suggesting that a major fluid-flow episode has not occurred recently, the methane peak, however, indicates that some active fluid advection persists.

\section{He-Isotope Ratios}

Helium is a conservative element, unaffected by chemical or biological reactions. Therefore, it uniquely defines its source. He-isotope ratios provide important constraints on the input of mantle gases into crustal systems. 
Table 1. Strontium concentration and isotopic composition of carbonatefree bulk sediments.

\begin{tabular}{lrrrr}
\hline $\begin{array}{c}\text { Core, section, } \\
\text { interval }(\mathrm{cm})\end{array}$ & $\begin{array}{c}\text { Depth } \\
(\mathrm{mbsf})\end{array}$ & $\begin{array}{c}\mathrm{Sr} \\
(\mathrm{ppm})\end{array}$ & ${ }^{87} \mathrm{Sr} /{ }^{86} \mathrm{Sr}$ & $2 \sigma$ \\
\hline 156-948C- & & & & \\
3X-5, 120-150 & 437.9 & 98.4 & & \\
8X-6, 120-150 & 487.6 & 104.9 & 0.714059 & 18 \\
9X-4, 115-150 & 494.2 & 103.6 & 0.711313 & 23 \\
10X-3, 110-150 & 502.4 & 120.0 & 0.714413 & 20 \\
13X-4, 115-150 & 532.6 & 128.7 & & \\
17X-2, 120-150 & 567.0 & 107.4 & 0.724502 & 19 \\
156-949B- & & & & \\
4X-1, 125-150 & 274.5 & 88.9 & 0.719553 & 22 \\
7X-6, 110-150 & 310.9 & 142.1 & & \\
15X-5, 110-100 & 367.2 & 82.0 & & \\
19X-2, 60-100 & 401.1 & 113.9 & & \\
156-949C- & & & & \\
4R-1, 0-4 & 425.2 & 155.3 & 0.718169 & 22 \\
25H-3, 110-150 & 460.7 & 84.4 & & \\
\hline
\end{tabular}

Seven pore-fluid samples were collected for He-isotope analyses; four from Hole 948C and three from Hole 949B. The samples were also analyzed for their Ne concentration, a valuable indicator of air contamination. Sampling drilled cores for pore fluids uncontaminated by air for He-isotopic composition is a rather delicate process. The results of $\mathrm{He}$ and $\mathrm{Ne}$ concentrations and $\mathrm{He}$-isotope ratios of the three samples found to be uncontaminated are listed in Table 2.

The He-isotopic compositions of these three samples from the vicinity of the Barbados décollement zone have $\mathrm{R} / \mathrm{R}_{\mathrm{A}}$ values $\left({ }^{3} \mathrm{He} /{ }^{4} \mathrm{He}\right.$ ratio relative to the atmospheric ratio) of 0.395 to 0.558 , which indicate that at the Barbados subduction zone, most of the He is crustal radiogenic and derived from production of ${ }^{4} \mathrm{He}$ from $\mathrm{U}$ and $\mathrm{Th}$ decay. Interestingly, the sample associated with the fluid conduit at the thrust fault at Site 949 (interval 156-949B-5X-2, 110-150 cm) has the most elevated He concentration, twice as high as the other two samples, and the isotopic composition is more radiogenic $\left(\mathrm{R} / \mathrm{R}_{\mathrm{A}}=\right.$ $0.395)$, indicating that more of its He has a crustal origin. The only other available data on He-isotopic composition of gases from the Barbados subduction zone are those reported in Poreda et al. (1988). Three of the four samples analyzed by them are totally devoid of mantle He, having $R / R_{A}$ values of $<0.02$, and a fourth sample has a primarily crustal ratio of 0.108 . All other subduction zones analyzed for He-isotope ratios contain considerably more mantle ${ }^{3} \mathrm{He}$ than at Barbados. At the Nankai subduction zone, the He-isotope ratios range from 0.523 at $400-600$ mbsf in the accreted section to 1.915 below the décollement (Kastner et al., 1993), and at six other subduction zones (Taiwan, New Zealand, Philippines, Indonesia, Thailand, and Alaska) where a mantle $\mathrm{He}$ component was documented, the ${ }^{3} \mathrm{He} /{ }^{4} \mathrm{He}$ values $(\mathrm{R})$ of the natural gases range from 0.5 to 3.8 times the atmospheric value $\left(\mathrm{R}_{\mathrm{A}}\right)$ (Poreda et al., 1988). The absence of mantle He at Barbados suggests that extensional tectonics is unimportant at this subduction system.

\section{CONCLUSIONS}

The most significant conclusions are as follows.

1. Unlike at Cascadia or Nankai, where terrigenous matter controls the in situ pore-fluid geochemistry, at Barbados in situ volcanic ash alteration and exchange with formation fluids in oceanic basement dominate the signatures.

2. Terrigenous smectite and/or mixed-layer smectite/illite dehydration and transformation reactions generate water, which dilutes the concentrations of major and minor components. In addition, the other components generated alter the chemistry and isotopic compositions of the pore fluids at the source and along the pathways of fluid migration by mixing with the pore

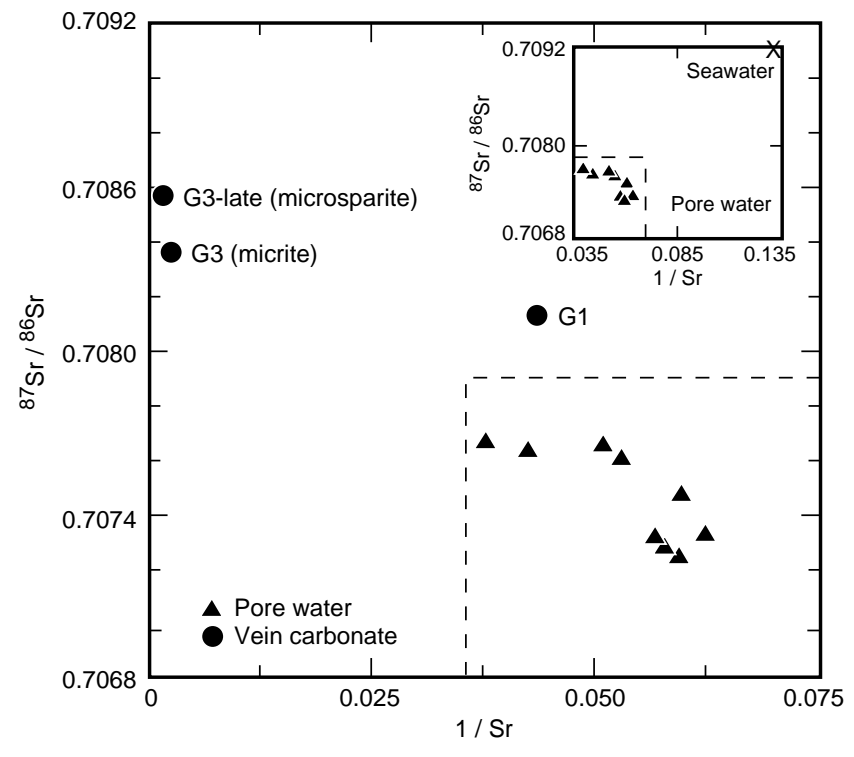

Figure 7. Mixing relations between ${ }^{87} \mathrm{Sr} /{ }^{86} \mathrm{Sr}$ values and $1 / \mathrm{Sr}$ concentrations (in ppm) of the Site 948 pore fluids from Type 4 carbonate veins, as described in Labaume et al. (Chapter 5, this volume). The pore fluids are from Hole 948C, and the veins are from Hole 948D. G1 and G3 mark the first and third generations of vein carbonates, respectively. The dashed lines delineate the pore-fluid data. The insert diagram in the top right emphasizes the relationship between the in situ pore-fluid field and modern seawater compositions (based on data in Kastner and Zheng [Chapter 29, this volume]).

fluids and induce elevated pore-fluid pressures. Thus, most of the expelled fluids are fresher than seawater and geochemically distinct from the in situ pore waters and seawater.

3. Geochemical profiles indicate focused, mainly lateral (eastward) flow along faults of a warm to hot low-Cl fluid, at both the normal and negative polarity sites.

4. The source of the low-Cl fluid, which is fresher than seawater by $\sim 18 \%$, enriched in methane, I, Ca, Sr, Ba, Mn, Mo, Zn, and Co concentrations, and isotopically distinct, is in sediments containing organic matter, situated arcward from Site 948 at a greater burial depth than drilled, where temperatures are elevated enough for efficient dehydration and transformation of the detrital hydrous clay minerals to occur.

5. The fluids in the accreted and underthrust sections are geochemically distinct.

6. The extent of $\mathrm{Cl}$ dilution and the spatial distribution of veins indicate that focused fluid flow is more intense in the accreted sediment section.

7. The geochemistry and mode of occurrence of vein-filling carbonate minerals indicate that the fluid flow at the top of the décollement zone at Site 948 is episodic and associated with hydrofracturing.

8. The present-day pore fluid is highly overprinted by in situ diagenetic reactions with volcanic glass, suggesting that a major fluid-flow episode has not occurred recently. Some fluid advection is, however, indicated by the minor methane peak at the top of the décollement at Site 948 .

9. The He isotopic composition of the pore fluids indicates some mantle-derived $\mathrm{He}$, but most of the $\mathrm{He}$ has a continental origin, as does the $\mathrm{Sr}$.

10. Preliminary interpretations of some of the geochemical data (i.e., Ba concentrations) seem to support the interpretation that the polarity and amplitude of the décollement seismic reflection are related to the fluid content and intensity of flow. Accordingly, the negative polarity of the décollement reflection 
Table 2. Helium and neon concentrations and helium isotopic values in pore waters.

\begin{tabular}{cccccc}
\hline $\begin{array}{c}\text { Core, section, } \\
\text { interval }(\mathrm{cm})\end{array}$ & $\begin{array}{c}\text { Depth } \\
(\mathrm{mbsf})\end{array}$ & $\begin{array}{c}\mathrm{He} \\
\left(10^{-8} \mathrm{~cm}^{3} / \mathrm{g}\right)\end{array}$ & $\mathrm{R} / \mathrm{R}_{\mathrm{A}}$ & $\begin{array}{c}\mathrm{Ne} \\
\left(10^{-8} \mathrm{~cm}^{3} / \mathrm{g}\right)\end{array}$ & Comments \\
\hline $\begin{array}{l}\text { 156-948C- } \\
\text { 4X-5, 110-150 }\end{array}$ & 448 & 9.99 & 0.516 & 17.14 & In the accreted section, $\sim 50 \mathrm{~m}$ above the décollement zone \\
$\begin{array}{l}\text { 156-949B- } \\
\text { 5X-2, 110-150 }\end{array}$ & 286 & 19.20 & 0.395 & 18.43 & $\begin{array}{l}\text { At a main thrust fault that is a fluid conduit } \\
\text { At the base of the décollement zone }\end{array}$ \\
22X-2, 110-150 & 430 & 9.02 & 0.558 & 16.35 & \\
\hline
\end{tabular}

Notes: The He isotopic results are reported as ${ }^{3} \mathrm{He} /{ }^{4} \mathrm{He}$ values $(\mathrm{R})$ relative to the atmospheric ratio $\left(\mathrm{R}_{\mathrm{A}}\right)$. The upper mantle value is eight times the atmospheric value $(\mathrm{RA})$; uncertainty of the error is 0.004

at Site 949 implies more fluid and/or higher pore-fluid pressure at this site than at Site 948 , where the polarity of the décollement reflection is normal.

\section{ACKNOWLEDGMENTS}

We are grateful to the shipboard scientific party for stimulating discussions during the cruise and to the crew and staff for their assistance and support on board the JOIDES Resolution. We thank J.B. Martin for his thoughtful and constructive comments. This research was supported by the National Science Foundation through the United States Science Committee (JOI-USSAC) grant and by an NSF Grant OCE 92-03879 to M. Kastner.

\section{REFERENCES}

Bangs, N.L.B., Shipley, T.H., and Moore, G.F., 1996. Elevated fluid pressure and fault zone dilation inferred from seismic models of the Northern Barbados Ridge décollement. J. Geophys. Res., 101:627-642.

Bangs, N.L.B., Westbrook, G.K., Ladd, J.W., and Buhl, P., 1990. Seismic velocities from the Barbados Ridge Complex: indicators of high pore fluid pressures in an accretionary complex. J. Geophys. Res., 95:87678782.

Bekins, B.A., McCaffrey, A.M., and Dreiss, S.J., 1995. Episodic and constant flow models for the origin of low-chloride waters in a modern accretionary complex. Water Resourc. Res., 31:3205-3215.

Bray, C.J., and Karig, D.E., 1985. Porosity of sediments in accretionary prisms and some implications for dewatering processes. J. Geophys. Res., 90:768-778.

Burke, W.H., Denison, R.E., Hethrington, E.A., Koepnick, R.B., Nelson, H.F., and Otto, J.B., 1982. Variation of seawater ${ }^{87} \mathrm{Sr} /{ }^{86} \mathrm{Sr}$ throughout Phanerozoic time. Geology, 10:516-519.

Carson, B., 1977. Tectonically induced deformation of deep-sea sediments off Washington and northern Oregon: mechanical consolidation. Mar. Geol., 24:289-307.

Carson, B., Suess, E., and Strasser, J.C., 1990. Fluid flow and mass flux determinations at vent sites on the Cascadia margin accretionary prism. $J$. Geophys. Res., 95:8891-8897.

Fisher, A.T., and Hounslow, M.W., 1990. Transient fluid flow through the toe of the Barbados accretionary complex: constraints from Ocean Drilling Program Leg 110 heat flow studies and simple models. J. Geophys. Res., 95:8845-8858

Foucher, J.-P., Le Pichon, X., Lallemant, S., Hobart, M.A., Henry, P., Benedetti, M., Westbrook, G.K., and Langseth, M.G., 1990. Heat flow tectonics and fluid circulation at the toe of the Barbados accretionary prism. $J$. Geophys. Res., 95:8859-8867.

Freed, R.L., and Peacor, D.R., 1989a. Geopressured shale and sealing effect of smectite to illite transition. AAPG Bull., 73:1223-1232.

, 1989b. Variability in temperature of smectite/illite reaction in Gulf Coast sediments. Clay Miner., 24:171-180.

Gieskes, J.M., Blanc, G., Vrolijk, P., Elderfield, H., and Barnes, R., 1990a. Interstitial water chemistry-major constituents. In Moore, J.C., Mascle, A., et al., Proc. ODP, Sci. Results, 110: College Station, TX (Ocean Drilling Program), 155-178.

Gieskes, J.M., Vrolijk, P., and Blanc, G., 1990b. Hydrogeochemistry of the northern Barbados accretionary complex transect: Ocean Drilling Project Leg 110. J. Geophys. Res., 95:8809-8818.

Han, M.W., and Suess, E., 1989. Subduction-induced pore fluid venting and the formation of authigenic carbonates along the Cascadia continental margin: implications for the global Ca-cycle. Palaeogeogr., Palaeoclimatol., Palaeoecol., 71:97-118.

Henry, P., Foucher, J.-P., Le Pichon, X., Sibuet, M., Kobayashi, K., Tarits, P., Chamot-Rooke, N., Furuta, T., and Schultheiss, P., 1992. Interpretation of temperature measurements from the Kaiko-Nankai cruise: modeling of fluid flow in clam colonies. Earth Planet. Sci. Lett., 109:355-371.

Henry, P., Lallémant, S.J., Le Pichon, X., and Lallémant, S.E., 1989. Fluid venting along Japanese trenches: tectonic context and thermal modeling. Tectonophysics. 160:277-291.

Jannasch, H.W. and Kastner, M., 1995. Long term continuous monitoring of fluid composition with an osmotically pumped fluid sampler. Dynamics of Lithosphere Convergence Workshop. Inter-Union Commission on Lithosphere (ICL) and Science Council of Japan, 4.

Kastner, M., 1996. Short and long-range monitoring of the composition and magnitude of ridge flank geochemical fluxes. FARA-IR Mid-Atlantic Ridge Symposium, Iceland: 3.

Kastner, M., Elderfield, H., Jenkins, W.J., Gieskes, J.M., and Gamo, T., 1993. Geochemical and isotopic evidence for fluid flow in the western Nankai subduction zone, Japan. In Hill, I.A., Taira, A., Firth, J.V., et al., Proc. ODP, Sci. Results, 131: College Station, TX (Ocean Drilling Program), 397-413.

Kastner, M., Elderfield, H., and Martin, J.B., 1991. Fluids in convergent margins: what do we know about their composition, origin, role in diagenesis and importance for oceanic chemical fluxes? Philos. Trans. R. Soc. London A, 335:243-259.

Kastner, M., Sample, J.C., Whiticar, M.J., Hovland, M., Cragg, B.A., and Parkes, J.R., 1995. Geochemical evidence for fluid flow and diagenesis at the Cascadia convergent margin. In Carson, B., Westbrook, G.K., Musgrave, R.J., and Suess, E. (Eds.), Proc. ODP, Sci. Results, 146 (Pt 1): College Station, TX (Ocean Drilling Program), 375-384.

Kulm, L.D., Suess, E., Moore, J.C., Carson, B., Lewis, B.T., Ritger, S.D., Kadko, D.C., Thornburg, T.M., Embley, R.W., Rugh, W.D., Massoth, G.J., Langseth, M.G., Cochrane, G.R., and Scamman, R.L., 1986. Oregon subduction zone: venting, fauna, and carbonates. Science, 231:561-566.

Laier, T., 1996. Mixing of methane and sulphate due to fluid flow in the Barbados accretionary prism. AAPG Convnt., 5: A79-A80.

Le Pichon, X., Henry, P., and Lallemant, S., 1990. Water flow in the Barbados accretionary complex. J. Geophys. Res., 95:8945-8967.

Linke, P., Suess, E., Torres, M., Martens, V., Rugh, W.D., Ziebis, W., and Kulm, L.D., 1994. In situ measurement of fluid flow from cold seeps at active continental margins. Deep-Sea Res. A, 41:721-739.

Martin, J.B., Kastner, M., and Elderfield, H., 1991. Lithium: sources in pore fluids of Peru slope sediments and implications for oceanic fluxes. Mar. Geol., 5:281-292.

McCorkle, D.C., Keigwein, L.D., Corliss, B.H., and Emerson, S.R., 1990. The influence of microhabitats on the carbon isotopic composition of deep sea benthic foraminifera. Paleoceanography, 5:161-185.

Moore, J.C., Mascle, A., Taylor, E., Andreieff, P., Alvarez, F., Barnes, R., Beck, C., Behrmann, J., Blanc, G., Brown, K., Clark, M., Dolan, J.F., Fisher, A., Gieskes, J., Hounslow, M., McLellan, P., Moran, K., Ogawa, Y., Sakai, T., Schoonmaker, J., Vrolijk, P., Wilkens, R.H., and Williams, C., 1988. Tectonics and hydrogeology of the northern Barbados Ridge: results from Ocean Drilling Program Leg 110. Geol. Soc. Am. Bull., 100:1578-1593.

Moore, J.C., Orange, D., and Kulm, L.D., 1990. Interrelationship of fluid venting and structural evolution: Alvin observations from the frontal accretionary prism. J. Geophys. Res., 95:8795-8808.

Moore, J.C., Shipley, T.H., Goldberg, D., Ogawa, Y., Filice, F., Fisher, A., Jurado, M.-J., Moore, G.F., Rabute, A., Yin, H., Zwart, G., and Brückmann, W., 1995. Abnormal fluid pressures and fault zone dilation in the Barbados accretionary prism: evidence from logging while drilling. Geology, 23:605-608. 
Moore, J.C., and Vrolijk, P., 1992. Fluids in accretionary prisms. Rev. Geophys., 30:113-135.

O'Neil, J.R., Clayton, R.N., and Mayeda, T.K., 1969. Oxygen isotope fractionation in divalent metal carbonates. J. Chem. Phys., 51:5547-5558.

Peacock, S.M., 1990. Fluid processes in subduction zones. Science, 248:329-337.

Perry, E., and Hower, J., 1970. Burial diagenesis in Gulf Coast pelitic sediments. Clays Clay Miner., 18:165-177.

Poreda, R.S., Jeffrey, A.W.A., Kaplan, I.R., and Craig, H., 1988. Magmatic helium in subduction zone natural gases. Chem. Geol., 71:199-210.

Shi, Y., and Wang, C.-Y., 1988. Generation of high pore pressures in accretionary prisms: inferences from the Barbados subduction complex. $J$. Geophys. Res., 93:8893-8910.

Shipley, T.H., Moore, G.F., Bangs, N.L., Moore, J.C., and Stoffa, P.L., 1994. Seismically inferred dilatancy distribution, northern Barbados Ridge décollement: implications for fluid migration and fault strength. Geology, 22:411-414.

Shipley, T.H., Ogawa, Y., Blum, P., et al., 1995. Proc. ODP, Init. Repts., 156: College Station, TX (Ocean Drilling Program).

Sibson, R.J., 1981. Fluid flow accompanying faulting: field evidence and models. In Simpson, D.W., and Richards, P.G. (Eds.), Earthquake Prediction: An International Review. Geophys. Monogr., Maurice Ewing Ser., Am. Geophys. Union, 4:593-603. von Huene, R., 1984. Tectonic processes along the front of modern convergent margins: research of the past decade. Anпи. Rev. Earth Planet. Sci., $12: 359-381$.

Vrolijk, P., Chambers, S.R., Gieskes, J.M., and O’Neil, J.R., 1990. Stable isotope ratios of interstitial fluids from the Northern Barbados Accretionary Prism, ODP Leg 110. In Moore, J.C., Mascle, A., et al., Proc. ODP, Sci. Results, 110: College Station, TX (Ocean Drilling Program), 189-205.

Vrolijk, P., and Sheppard, S.M.F., 1991. Syntectonic carbonate veins from the Barbados accretionary prism (ODP Leg 110): record of paleohydrology. Sedimentology, 38:671-690.

Whiticar, M.J., Hovland, M., Kastner, M., and Sample, J.C., 1995. Organic geochemistry of gases, fluids, and hydrates at the Cascadia accretionary margin. In Carson, B., Westbrook, G.K., Musgrave, R.J., and Suess, E. (Eds.), Proc. ODP, Sci. Results, 146 (Pt 1): College Station, TX (Ocean Drilling Program), 385-397.

Date of initial receipt: 4 September 1996

Date of acceptance: 15 January 1997

Ms 156SR-035 